
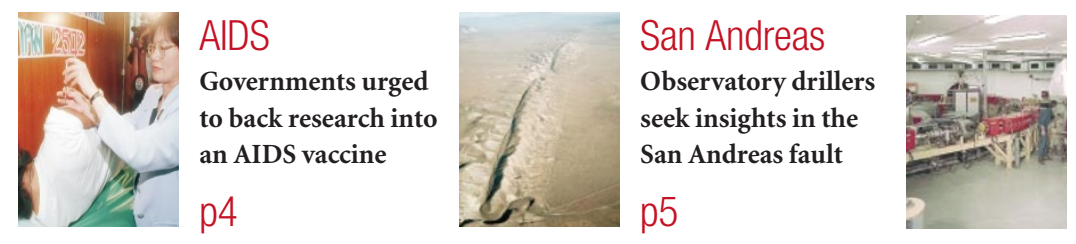

Synchrotron

Middle East tour aims

to raise support for

threatened project

p6

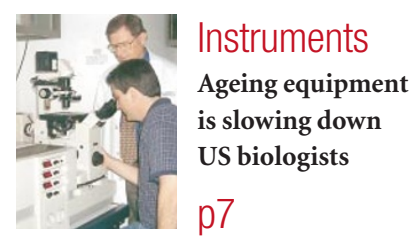

\title{
Japan acts to speed technology transfer from universities
}

Tokyo

A Japanese law that takes effect this autumn will promote technology transfer from universities and government laboratories to the commercial sector.

The technology-transfer bill, based on the influential Bayh-Dole legislation passed almost 20 years ago in the United States, is part of a policy initiative aimed at improving links between government, industry and academia. It underpins prime minister Keizo Obuchi's Millennium Project, which aims to

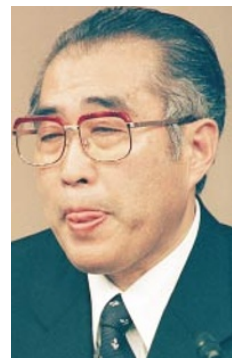

foster new industries in areas such as biotechnology, information technology and environmental engineering.

Obuchi's project aims to make industry competitive by increasing collaboration with government-run research instiObuchi: fostering tutes. It will step up supnew industries. port for genome-related research, including a plan to decode a third of human gene sequences and to create a national centre for bioinformatics by 2001 (see Nature 400, 389; 1999).

Industry has welcomed the new framework. Until now, rights to patents produced from government-funded research have belonged to the national treasury, and could not be assigned to the private sector without complex legal procedures. The new measures will encourage universities to collaborate with industry to promote the application of government-funded science - allowing technology licensing organizations (TLOs), which advise on the commercial exploitation of university research, to obtain patent rights to inventions made at universities.

The technology-transfer law will grant awardee organizations first rights to a patent fully or partially funded by the government, allowing industrial research partners to retain title to inventions.

The Ministry of International Trade and Industry (MITI) says the licensing income of US universities alone totalled US $\$ 0.7$ billion in 1998, while the combined licensing income of Japan's universities and national research institutes is only US\$2.7 million.

"University research is potentially a large source of income, as well as new technology," says Masahiro Hashimoto, head of industryuniversity collaboration at MITI. "But the main problem is the reluctance of university researchers to become involved in profitmaking activities."

Japan's civil service law forbids commercial activity by employees of national universities, and bans academics from holding external posts at private companies (see Nature 399, 624; 1999), though the government is planning to relax these restrictions.

"Japanese universities seem to be allergic to commercial activities: many still see involvement in such activities as a sign of frivolity," says Takeshi Onoda of the Japan Federation of Economic Organizations, the former director of Mitsubishi Chemicals .

The transfer of university research will bring immediate benefits to the commercial sector, but not necessarily to the universities themselves, says Onoda. "Successful application of the new technology-transfer law depends on whether individual researchers will be able to promote the commercialization of their inventions, and how mediating organizations such as TLOs succeed in assisting such endeavours."

Although Obuchi's Millennium Project envisages the emergence of new industries over the next ten years, some observers predict that university technology transfer in Japan will take up to 15 years to develop.

"There is a need to develop a proper infrastructure for collaboration between industry, academia and the government, and we are 20 years behind the United States in this area," says Onoda.

Asako Saegusa

\section{Crop trials seek to allay public fears}

Tokyo

Japan's Ministry of Agriculture, Forestry and Fisheries (MAFF) has announced plans for a five-year project to examine potential long-term risks of genetically modified (GM) crops to the environment. The move comes amid growing signs of consumer resistance to GM products in Japan.

Researchers at the National Institute of Agro-Environmental Sciences, in Tsukuba, will test the possibility of gene transfer from GM oilseed rape to wild plant species.

GM oilseed rape, approved in Japan for agricultural purposes, is an outbreeding species with many wild relatives in Japan. If gene transfer is judged likely, MAFF will assess whether this would have any harmful ecological effects.

According to MAFF, results from this research will be reflected in its new safety guidelines, which are currently being revised to incorporate more rigorous criteria for testing the safety of GM crops. This is partly due to the recent publication of research indicating that pollen from $\mathrm{Bt}$ corn can harm the larvae of monarch butterflies. The ministry decided in June to suspend approval of all $B t$ crops for agricultural purposes until it has established criteria for evaluating the safety of GM crops (see Nature 399, 719; 1999).

Although MAFF officials predict that the risks of GM crops are negligible, they emphasize the importance of allaying public concern by tightening the safety regulations.

In the wake of last month's decision by the government to label food products containing detectable GM ingredients (see Nature 400, 605; 1999), Japanese companies - none of which has yet commercialized GM products - are finding it hard to overcome the negative image of GM foods.

Recent government decisions on GM organisms "are a real setback for Japan's GM industry," says Atsushi Suzuki, an adviser to Japan Tobacco, which is involved in the development of GM rice.

Some companies are already retreating. Kirin Beer, one of Japan's largest breweries, last week announced it would abandon its research into GM tomatoes, and promised its beer would be GM-free by 2001 . 